\title{
Meningkatkan Pemahaman Masyarakat Tentang Tindak Pidana Korupsi Khususnya Penyalagunaan Dana Desa
}

\author{
Arsyad, Umar Hasan, Andi Najemi, Yulia Monita \\ Fakultas Hukum Universitas Jambi
}

\begin{abstract}
ABSTRAK
Kegiatan Pengabdian Pada Masyarakat telah dilakukan di aula Kantor Desa.Sungai Bunggur Kecamatan Kumpeh kabupaten Muaro Jambi pada tanggal 16 Juli 2020 dengan pertemuan tatap muka. Tujuan Pengabdian Pada masyarakat ini adalah mensosialisasikan kepada Masyarakat Undang-Undang No.6 Tahun 2014 Tentang Desa. Hal tersebut tidak terlepas dari tingginya perbuatan korupsi yang berkaitan dengan kerugian negara yang dilakukan oleh penyelenggara negara khususnya kepala desa, dikarenakan masih minimnya tingkat pengetahuan dan pemahaman dari penyelenggara negara dalam hal penyalahgunaan keuangan desa. Tujuan Pengabdian Masyarakat ini untuk meningkatkan pengetahuan dan pemahaman dari penyelenggara negara dalam hal penyalahgunaan keuangan desa.Hasil dari Kegiatan ini menunjukkan bahwa animo masyarakat mengikuti kegiatan ini cukup tinggi, karena dapat meningkatkan pemahaman yang berkaitan dengan pengetahuan aparat desa dalam hal penggunaan dana desa agar penggunaannnya tidak menyalahi peraturan yang berlaku. Metode pelaksanaan penyuluhan hukum yang dilakukan bermitra dengan Kepala Desa Sungai Bunggur, dengan metode: penyampaian materi yaitu diskusi dan tanya jawab,
\end{abstract}

Kata Kunci: Keuangan Desa; Tindak Pidana Korupsi

\section{PENDAHULUAN}

\section{Analisis Situasi}

Peraturan yang mengatur tentang Desa telah dibuat oleh pemerintah Indonesia. Dalam aturan tersebut mengatur adanya kewenangan desa untuk mengelola sendiri keuangannya dan mengembangkan desanya. Melimpahnya sumber daya alam desa, membuat desa dapat membangun desanya dengan baik, sehingga bisa meningkatkan penghasilan desa dan meningkatkan kesejahteraan warganya.. Adapun penjelasan yang dimaksud dengan keuangan desa menurut aturan atau Undang-Undang No.6 Tahun 2014 Tentang Desa, bahwa: "Desa mempunyai hak dan kewajiban terhadap semua yang ada di desa yang dapat dinilai dengan uang maupun segala sesuatu berupa uang maupun barang yang berhubungan dengan pelaksanaanaan hak dan kewajiban yang ada pada desa, sehingga dapat menciptakan pendapatan belanja, pembiayaan dan pengelolaan keuangan desa"1

Adanya bantuan dana dari Pemerintah untuk desa untuk dapat digunakan dalam mengembangkan desanya lebih maksimal dalam mengelola potensi yang ada pada desanya. Dengan adanya bantuan yang diberikan kepada desa menimbulkan persoalan baru., yang mana banyak dana desa disalahgunakan dalam hal penggunaannya. Ada beberapa perangkat desa, seperti pihak kepala desa dan Badan Permusyawaratan Desa, dalam melaksanakan penggunaan keuangan desa tidak cocok dengan peruntukannya atau menyalahi kewenangan yang ada padanya., sehingga Kepala Desa mapun Badan Permusyawaran Desa yang melakukan penimpangan terhadap dana desa tersebut dapat dikategorikan telah melakukan tindak pidana korupsi. Sebagaimana yang dirumuskan dalam Undang-Undang No. 31 Tahun 1999 jo

${ }^{1}$ Yusrianto Kadir, Roy Marthen Moonri, Pencegahan Korupsi Dalam Pengelolaan Dana Desa, Jurnal IUS, Volume 6 No.3, Tahun 2018 
Undang-Undang No. 20 Tahun 2001 Tentang Pemberantasan Tindak Pidana Korupsi. Rumusan ketentuan yang dapat dikenakan terhadap Kepala Desa maupun perangkatnya yang melakukan penyalahgunaan Keuangan Desa adalah Pasal 2 dan Pasal 3. ${ }^{2}$

Berdasarkan rumusan Pasal tersebut, maka ada beberapa unsur yang harus terpenuh, yaitu:

1). Unsur pertama, bahwa yang dapat dipertanggungjawabkan sebagai pelaku adalah manusia yang memenuhi kriteria pertanggungjawaban pidana, dan korporasi. Adapun korporasi dalam hal ini adalah korporasi yang mendapat keuntungan akibat dari perbuatan korupsi tersebut.

2). Unsur yang kedua adalah: akibat dari perbuatan yang dilakukannya membuat pelaku sendiri maupun orang lain mendapatkan kekayaan, akibat dari perbuatan tersebut.

3). Unsur ketiga adalah: Perbuatan yang dilakukan oleh pelaku tidak sesuia atau bertentangan dengan ketentuan hukum yang berlaku. .

Dari rumusan Pasal 3, yaitu “

1) Unsur pertama adalah: Yang dapat dipertanggungjawabkan sebagai pelaku adalah manusia yang memenuhi kriteria pertanggungjawaban pidana, korporasi. Adapun korporasi dalam hal ini adalah korporasi yang mendapat keuntungan akibat dari perbuatan korupsi tersebut, Orang lain adalah selain diri sendiri, korporasi masuk kategori orang lain.

2) Unsur kedua adalah: adanya penyalahgunaan kekuasaan, peluang atau fasilitas yang berada padanya, sehingga dapat memberikan keuntungan kepada diri pribadi maupun orang lain termasuk korporasi

3) Adanya kekuasaan atau pangkat yang melekat pada diri si pelaku, akibat perbuatannya mengakibatkan kerugian keuangan negara atau perekonomian negara.

Berkaitan dengan Pengelolaan Keuangan Desa, maka perangkat desa harus mengetahui atau menerapkan aturan yang mengatur Keuangan Desa. Adapun peeraturan tersebut adalah: "Peraturan Menteri Dalam Negeri Nomor 113 Tahun 2014 tentang Pengelolaan Keuangan Desa. Dalam pengelolaannya tidak boleh bertentangan degan asas-asas sebagai berikut:

1) Transparan, berarti dalam penggunaan keuangan desa harus terbuka, jelas dan konkrit.

2) Akuntabel, berarti penggunaan keuangannya dapat dipertanggungjawabkan

3) Partisipatif, berarti setiap warga punya hak untuk berpartisipasi dalam menentukan keuangan desa.

4) Tertib dan disiplin, berarti dalam penggunaan keuangan harus sesuai dengan perencanaan yang telah disusun.

Berdasarkan asas-asas tersebut dalam pengelolaan desa, yang paling dominan dilanggar oleh kepala desa adalah kurang transparan. Kepala desa kurang melibatkan masyarakat dalam penyusunan dan pengontrolan penggunaan keuangan desa. Kurang melibatkan lembagalembaga desa seperti Badan Permusyawaratan Desa (BPD). ${ }^{3}$

Terjadinya penyalahgunaan dana desa tersebut di atas, tentu saja membuat kita prihatin, hal tersebut tentunya tidak sesuai dengan keadaan yang diharapkan karena mengingat keberadaan kepala desa beserta perangkat desa dalam melaksanakan tugas dan wewenangnya sebagai pihak pemerintah Desa yang seharusnya sebagai pihak yang melayani, mengayomi dan mengabdi pada kepentingan masyarakat desa. Hal ini juga akan berpengaruh terhadap proses pembangunan desa, karena dalam pengelolaan keuangan desa berjalan tidak sebagaimana mestinya di Desa.

\footnotetext{
${ }^{2}$ Lihat Pasal 2, 3 UU No.31 tahun 1999 jo UU No.20 Tahun 2001 Tentang Tindak Pidana Korupsi ${ }^{3}$ Ibid
} 
Beberapa bentuk perbuatan penyalahgunaan desa yang banyak dilakukan Pemerintah Desa yaitu Penggelapan, penyalahgunaan anggaran, penyalahgunaan wewenang, pungutan liar, markup anggaran, laporan fiktif, pemotongan anggaran dan suap. Adapun bentuk modus yang dilakukan oleh Pemerintah desa, yaitu dengan markup anggaran dengan melakukan rancangan anggaran biaya melebihi harga pasaran, membuat kegiatan palsu yang anggarannya menggunakan dana desa dan membuat penipuan secara bersekongkol dalam proyek yang didanai dana desa. Banyaknya perbuatan yang mengakibatkan kerugia negara tentunya memerlukan solusi, agar kerugian negara akibat dari tindak pidana korupsi dapat dicegah atau ditekan seminimal mungkin.

Dari penjelasan yang telah dikemukakan, maka Tim pengabdian pada masyarakat dalam kegiatan ini, akan melakukan Penyuluhan Hukum Tentang Pemahaman Masyarakat Terhadap Tindak Pidana Korupsi khususnya Dalam Penyalahgunaan Dana Desa. Khususnya di Desa Bungur Kumpeh Kabupaten Muaro Jambi .

\section{Permasalahan Mitra}

Ada beberapa kepala desa yang ada beberapa daerah di Provinsi Jambi dalam masa pemerintahannya telah melakukan sejumlah tindakan bertentangan dengan posisi dan kedudukannya sebagai seorang Kepala Desa dalam pengelolaan keuangan desa, tindakan tersebut yaitu berupa proses pengelolaan keuangan desa yang tidak dilaksanakan secara transparan yang digolongkan sebagai tindak pidana korupsi. Berdasarkan hasil penelitian, bahwa tingginya perbuatan korupsi yang berkaitan dengan kerugian negara yang dilakukan oleh penyelenggara negara khususnya kepala desa, dikarenakan masih minimnya engetahuan dan pemahaman dari penyelenggara negara dalam hal penyalahgunaan keuangan desa ${ }^{4}$.

Penyalahgunaan dana desa yang terjadi di beberapa wilayah hukum di Kabupaten Muaro Jambi, merupakan salah satu hal yang menandakan adanya suatu usaha yang harus dilakukan, yaitu mulai dari penegakan hukumnya maupun dalam hal pemahaman aparat penegak hukum yaitu kepala desa. Oleh sebab itu perlu dilakukan upaya pencegahan dan penanggulangan guna mengatasi dan memberantas tindak pidana tersebut khususnya penyalahgunaan dana desa.

Permasalahannya bagaimanakah pelaksanaan penanggulangan penyalahgunaan dana desa yang dilakukan oleh aparat penegak hukum dalam menerapkan ketentuan normatif tersebut apakah telah benar-benar mampu diwujudkan oleh penegak hukum di lapangan, menjadi peristiwa hukum konkrit (dassein), berupa penanggulangan tindak pidana korupsi dana desa, sehingga tidak terjadi lagi tindak pidana korupsi dana desa atau setidaknya dapat ditekan intensitasnya.

Pengelolaan dana desa di Kabupaten Muarojambi, Provinsi Jambi masih banyak yang menyimpang. Penyimpangan atau penyalahgunaan dana desa di kabupaten itu diduga akibat ketidaktahuan para kepala desa mengenai tata kelola dana desa. Salah kelola dana desa itu menyebabkan banyak dana desa yang menguap alias tidak jelas penggunannya. Demikian diungkapkan Kepala Inspektorat Kabupaten Muarojambi, Budi Hartono terkait hasil audit atau pemeriksaan penggunaan dana desa Muarojambi tahun 2019 di Muarojambi,

Guna mengetahui permasalahan yang dihadapi, maka yang merupakan pokok persoalan dalam kegiatan ini, adalah:

1. Mengapa Perangkat Desa perlu mengetahui perbuatan yang masuk kategori perbuatan penyalahgunaan dana desa dan masuk perbuatan tindak pidana korupsi?

2. Faktor apakah yang menjadi penyebab penyalagunaan dana desa?

${ }^{4}$ Hanif Nurchlis, Pertumbuhan dan Penyelenggaraan Pemerintahan Desa, Erlangga, Jakarta, 2011, hlm. 
3. Apakah solusi yang dapat diberikan, agar dapat dilakukan pencegahan dalam penyalahgunaan dana desa

\section{METODE PELAKSANAAN}

Kegiatan melibatkan masyarakat sebagai sasarannya, adapun masyarakat yang terpilih adalah masyarakat sekitar namun sasaran diutamakan para perangkat desa. Pelaksanaan pengabdian ini juga melibatkan Kepala Desa sebagai mitra kerja sama, Pengabdian Pada Masyarakat ini menggunakan metode pendekatan berupa sosialisasi. Dengan harapan, setelah pelaksanaan kegiatan sosialisasi ini tumbuh pemahaman mengenai Peraturan yang berkaitan pengunaan dana desa, karena tidak menutup kemungkinan adanya penyalahgunaan dana desa yang dilakukan oleh aparat desa.

Berdasarkan alur kerja pengabdian tersebut, tim akan membagi tahapan pelaksanaan kegiatan pengabdian menjadi beberapa tahapan, yaitu Tahapan persiapan, tahapan pelaksanaan, dan tahapan evaluasi yang diuraikan sebagai berikut:

Adapun langkah-langkah yang dilaksanakan oleh Tim bermitra dengan Kepala Desa Bunggur Kec. Kumpeh Kabupaten Muaro jambi, yaitu:

1. Tahap Persiapan

2. Penentuan Materi Kegiatan

3. Pelaksanaan Kegiatan Pokok

4. Evaluasi hasil kegiatan.

5. Penyusunan Laporan akhir

\section{METODE PELAKSANAAN KEGIATAN}

Dalam Program Pelaksanaan kegiatan penyuluhan hukum dilakukan melalui beberapa metode, diantanya:

1. Metode ceramah, yaitu merupakan metode untuk menyampaikan materi kepada peserta sesuai dengan yang ditentukan Tim Pelaksana.

2. Metode Tanya Jawab, yaitu metode yang dilakukan untuk mengetahui respon pengetahuan atau tingkat pemahaman peserta terhadap materi yang telah disampaikan.

3. Metode diskusi dan tanya jawab, yaitu tim pengabdian memberikan kesempatan kepada peserta untuk menyampaikan pertanyaannya berkaitan dengan materi yang telah diampaikan.

\section{HASIL DAN PEMBAHASAN}

\section{Kewenangan Kepala Desa}

Kegiatan Pengabdian ini melibatkan masyarakat Desa Bunggur Kecamatan Kumpeh Kabupaten Muaro Jambi sebagai sasarannya, adapun masyarakat yang terpilih adalah Kepala Desa beserta aparat desa Bunggur. . Pengabdian terhadap masyarakat ini menggunakan metode pendekatan berupa sosialisasi. Dengan harapan, setelah pelaksanaan kegiatan sosialisasi ini tumbuh pemahaman mengenai Peraturan dalam penggunaan dana desa untuk digunakan sesuai dengan peruntukannya.

Ada beberapa aparat desa maupun perangkat Desa dalam pelaksanaan pengelolaan keuangan desa dianggap melaksanakan sejumlah tindakan yang tidak sesuai dengan kedudukan dan kewenangannya Oleh karena itu aparat desa harus memiliki pengetahuan tentang kewenangan kepala desa, seperti yang diatur dalam ketentuan Pasal 26 ayat (1) dan (2) Undang-Undang Nomor 6 Tahun 2014 tentang Desa.. Dengan kegiatan ini, diharapkan 
kepada masyarakat untuk kedepannya dalam tidak ditemukan lagi penyalahgunaan dana desa untuk kepentingan pribadi.

Menjawab permasalahan yang berkembang tersebut, solusi yang ditawarkan melalui diskusi dan tanya jawab Tim Pengabdian dengan masyarakat mengenai ruang lingkup Peraturan yang mengatur tentang kewenangan kepala desa, sebagaimana ketentuan yang telah disebutkan. Oleh karena itu setiap Kepala desa harus mentaati. Ketentuan yang berkaitan dengan keuangan desa, yaitu:

a. Kepala desa mempunyai kewenangan dalam pengelolaan Keuangan dan Aset Desa;

b. Kepala desa menentukan Anggaran Pendapatan dan Belanja desa dengan pertimbangan yang transparan

c. Kepala desa punya kewajiban untuk melakukan pembinaan, mengembangkan dan menumbuhkan tingkat ekonomi Desa untuk meningkatkan perekonomian masyarakat yang bersifat produktif untuk dipergunakan sebesar-besarnya kesejahteraan masyarakat Desa.

d. Kepala desa membuat usulan untuk mendapatkan bantuan dari negara guna meningkatkan kesejahteraan masyarakatnya;

e. Kepala desa dalam melaksanakan perencanaan pembangunan desanya harus berkoordinasi dengan masyarakat.;

f. Kepala desa tidak boleh melakukan perbuatan yang bertentangan dengan aturan yang berlaku dan melaksanakan tugasn lain yang diberikan juga berdasarkan ketentuan peraturan yang berlaku.

Pelaksanaan tugas dan wewenang Kepala Desa mengacu pada ketentuan Pasal 27 Undang-Undang Nomor 6 Tahun 2014 tentang Desa. Sedangkan Pasal 26 mengatur tentang hak, dan kewajiban Kepala Desa meliputi:.

a. Melaporkan kepada Bupati/Walikota setiap akhir tahun anggaran tentang pengelolaan Pemerintahan Desa;

b. Melaporkan kepada Bupati/Walikota tentang pengelolaan Pemerintahan Desa pada akhir masa jabatannya;

c. Melaporkan tentang pengelolaan pemerintahan secara tertulis kepada Badan Permusyawaratan Desa setiap akhir tahun anggaran; dan

d. Menyampaikan informasi kepada masyarakat tentang pengelolaan pemerintahan secara tertulis setiap akhir tahun anggaran.

Berkaitan dengan kewajiban Kepala desa, maka ditemukan pada beberapa daerah dalam masa pemerintahannya telah melakukan sejumlah tindakan bertentangan dengan posisi dan kedudukannya sebagai seorang Kepala Desa dalam pengelolaan keuangan desa, tindakan tersebut yaitu berupa proses pengelolaan keuangan desa yang tidak dilaksanakan secara transparan yang digolongkan sebagai tindak pidana korupsi. Meningkatnya perilaku korupsi tidak terlepas dari kegiatan penyelenggara Negara.yang tidak mematuhi peraturan yang berlaku. Sebagai penyelenggara negara Kepala Desa merupakan pemegang kekuasaan pengelolaan pemerintahan di desa, tentunya wajib mengetahui peraturan yang melarang penggunaan dana desa yang tidak sesuai dengan peruntukannya, karena dapat dikenakan tindak pidana korupsi.

Pengaturan mengenai perbuatan yang dilarang berkaitan dengan penggunaan dana desa diatur dalam Pasal 2-20. Adapun Pasal 2 nya menentukan:

(1) Pidana penjara dan denda dapat dikenakan kepada orang yang melakukan perbuatan yang dapat menguntungkan diri sendiri atau orang lain atau suatu korporasi yang dapat merugikan keuangan negara atau perekonomian negara.

(2) Pidana mati dapat diterapkan apabila dilakukan dalam kondisi tertentu, misalnya dalam kondisi negara mengalami bencana. 
Terjadinya permasalahan tersebut di atas, hal tersebut tentunya tidak sesuai dengan keadaan yang diharapkan karena mengingat keberadaan kepala desa beserta perangkat desa dalam melaksanakan tugas dan wewenangnya sebagai pihak pemerintah Desa yang seharusnya sebagai pihak yang melayani, mengayomi dan mengabdi pada kepentingan masyarakat desa. Oleh karena itu dibutuhkan profil kepala desa beserta perangkat desa yang benar-benar potensial dan bertanggung jawab agar proses pembangunan dalam pengelolaan keuangan desa dapat berjalan sebagaimana mestinya di Desa.

\section{Keuangan Desa}

Penjelasan tentang keuangan desa diatur dalam Pasal 71, yaitu segala bentuk hak dan kewajiban Desa yang bisa dinilai dengan uang serta segala sesuatu berupa uang dan barang yang berhubungan dengan pelaksanaan hak dan kewajiban Desa untuk penyelengaraan pembangunan desa." Selanjutnya, pengaturan mengenai keuangan desa dan hal lain yang terkait dengannya dijabarkan lebih lanjut dalam berbagai peraturan, di antaranya Peraturan Pemerintah Nomor 43 Tahun 2014 tentang Peraturan Pelaksanaan Undang-Undang Nomor 6 Tahun 2014 tentang Desa, Peraturan Pemerintah Nomor 60 Tahun 2014 tentang Dana Desa yang Bersumber dari APBN, Peraturan Pemerintah Nomor 22 Tahun 2015 tentang Perubahan atas Peraturan Pemerintah Nomor 60 Tahun 2014, Peraturan Pemerintah Nomor 47 Tahun 2015 tentang Perubahan atas Peraturan Pemerintah Nomor 43 Tahun 2014, Permendagri Nomor 113 Tahun 2014 tentang Pengelolaan Keuangan Desa, Permenkeu Nomor 241/PMK.07/2014 tentang Pelaksanaan dan Pertanggungjawaban Transfer ke Daerah dan Dana Desa, Permenkeu No. 250/PMK.07/2014 tentang Pengalokasian Transfer ke Daerah dan Dana Desa, Permenkeu No. 93/PMK.07/2015 tentang Tata Cara Pengalokasian, penyaluran, Penggunaan, Pemantauan, dan Evaluasi Dana Desa, dan Permendes PDTT No. 5 Tahun 2015 tentang Prioritas Penggunaan Dana Desa. ${ }^{5}$

Dalam hal melakukan pengelolaan dana desa yang sumber dananya diperoleh dari APBDesa, bantuan pemerintahan pusat, dan bantuan pemerintahan daerah. Penyelenggaraan urusan pemerintahan daerah yang diselenggarakan oleh pemerintahan desa didanai dari APBD, sedangkan penyelenggaraan urusan pemerintahan pusat yang diselenggarakan oleh pemerintahn desa didanai dari APBN. ${ }^{6}$

Pasal 72 Undang-Undang Nomor 6 Tahun 2014 tentang Desa menentukan:

(1) Penghasilan desa sebagaimana dimaksud dalam Pasal 71 ayat (2) bersumber dari:

a. Penghasilan asli dari desa yang diperoleh dari hasil usaha, hasil aset, swadaya dan partisipasi, gotong royong, dan lain-lain yang bersumber langsung dari desa;

b. Anggaran Pendapatan dan Belanja Negara;

c. Diperoleh dari pungutan pajak daerah dan retribusi daerah Kabupaten/Kota;

d. Anggaran dana Desa yang merupakan bagian dari dana perimbangan yang diterima Kabupaten/Kota;

e. bantuan keuangan dari Anggaran Pendapatan dan Belanja Daerah Provinsi dan Anggaran Pendapatan dan Belanja Daerah Kabupaten/Kota;

f. Sumbangan dan hibah dari pihak ketiga yang tidak mengikat dan

g. Pendapatan Desa lain yang sah.

Setiap desa diberi kewenangan untuk mengelola dana desanya sebagaimana yang terdapat dalam Undang-Undang Nomor 6 Tahun 2014 tentang Desa dan Peraturan Pemerintah

\footnotetext{
${ }^{5}$ Pusat Inovasi Tata Pemerintahan Lembaga Administrasi Negara, Policy Paper Pengelolaan Keuangan Desa Pasca Undang-Undang Nomor 6 Tahun 2014, Cetakan 1 - Jakarta: Pusat Intan Lan, 2015, hlm. 3.

${ }^{6} \mathrm{HAW}$. Widjaja, Op. Cit., hlm. 81.
} 
Nomor 22 Tahun 2015 tentang Perubahan Atas Peraturan Pemerintah Nomor 60 Tahun 2014 tentang Dana Desa yang bersumber dari APBN.

Permasalahan dana desa sangat beragam, terdiri dari aspek kebijakan lembaga, aspek pengaturan, aspek pengawasan dan aspek sumber daya manusia. Aspek kebijakan lembaga yakni belum adanya petunjuk tekhnis dalam pengelolaan keuangan desa., tidak transparannya formula pembagian dana desa dalam Peraturan Pemerintah Nomor 22 Tahun 2015 dan hanya didasarkan atas dasar pemerataan.

Pengelolaan dana desa sepenuhnya milik hak desa dan ke depan akan menjadi dana alokasi khusus yang wajib ditransfer langsung dari pemerintah pusat ke pemerintahan desa. Kemendes PDTT, yang banyak mengurusi dana desa saat ini, lebih berkonsentrasi pada progres penyerapan anggarannya saja.

Pengelolaan dan pengalokasian Dana Desa yang merupakan amanat Undang-Undang Nomor 6 Tahun 2014 tentang Desa serta Peraturan Pemerintah Nomor 66 Tahun 2014 tentang Dana Desa yang Bersumber Dari APBN.

Berkaitan dengan Pengelolaan Keuangan Desa, maka perangkat desa harus mengetahui atau menerapkan aturan yang mengatur Keuangan Desa. Adapun peeraturan tersebut adalah: "Peraturan Menteri Dalam Negeri Nomor 113 Tahun 2014 tentang Pengelolaan Keuangan Desa. Keungana desa dalam pengelolaannya berdasarkan asas-asas:

1) Transparan, berarti dalam penggunaan keuangan desa harus terbuka, jelas dan konkrit.

2) Akuntabel, berarti penggunaan keuangannya dapat dipertanggungjawabkan

3) Partisipatif, berarti setiap warga punya hak untuk berpartisipasi dalam menentukan keuangan desa.

4) Tertib dan disiplin, berarti dalam penggunaan keuangan harus sesuai dengan perencanaan yang telah disusun.

\section{Faktor Yang Menyebabkan Tindak Pidana Korupsi Dana Desa}

Meningkatnya angka kasus korupsi dalam pengelolaan anggaran desa tentunya membuat kita ikut prihatin, untuk itu perlu kita ketahui mengapa hal tersebut bisa terjadi. Terjadinya Korupsi di desa berkembang karena beberapa faktor yang saling berkaitan: pertama, lemahnya pengawasan institusi (lembaga) yang memiliki otoritas dalam pengawasan. Dalam hal ini yang melakukan pengawasan adalah BPKP dan BPK untuk mengawasi, memeriksa dan mangudit pengelolaan anggaran desa. Kedua, rendahnya partisipasi masyarakat dalam pengawasan APBDes. Peksanaan program desa dalam penyaluran dana desa, masyarakat tidak banyak terlibat dalam perencanaan, pelaksanaan dan evaluasi terhadap dana desa. Ketiga, rendahnya transparansi dan akuntabilitas pengelolaan keuangan desa. Rendahnya transparansi dan akuntabilitas pengelolaan keuangan desa karena hegemoni kewenangan kepala desa selaku Pemegang Kekuasaan Pengelolaan Keuangan Desa (PKPKD). Harus diakui budaya feodalisme yang masih mengakar kuat di mayoritas desa di Indonesia memungkinkan kepala desa memiliki kekuasaan "mutlak" dalam perencanaan, pelaksanaan pengelolaan keuangan desa. Perangkat desa, dan BPD lebih terkesan sebagai kekuatan pendukung kepentingan kepala $\operatorname{desa}^{7}$.

Berdasarkan hasil penelitian, ada beberapa faktor yang menyebabkan tindak pidana korupsi dana desa di Kabupaten Muaro Jambi, antara lain:

1. Kurangnya keahlian aparat pemerintah desa

2. Kurang nya transparansi dalam pengelolaan keuangan desa

${ }^{7}$ Trisno Yulianto, Desa Nol Korupsi, Undip, Koordinator Forum Kajian dan Transparansi Anggaran (Forkata), diakses Tanggal 27 Agustus 2020 
3. Kurangnya pengawasan yang dilakukan pemerintah, masyarakat dalam penggunaan desa

4. Tingginya penggelembungan (mark up) harga

5. Pelaksanaan kegiatan fisik yang tidak sesuai dengan perencanaan

6. Kebiasaan masyarakat dengan memberikan uang atau barang sebagai ucapan terimakasih.

7. Pengelolaan dana desa (DD) dan Alokasi dana desa tidak sesuai Rancangan Anggaran Biaya (RAB)

8. Pembelanjaan barang tidak mengacu pada RAB

9. Keterbatasan pengetahuan aparat desa dalam memahami aplikasi SisKeuDes

10. Dalam penggunaan dana desa tidak mematuhi tidak/kurang sesuai dengan Permen desa tentang prioritas penggunaan dana desa ${ }^{8}$

Dari beberapa Faktor penyebab penyalahguna dana desa, yang paling prinsip adalah kurang melibatkan masyarakat dalam proses perencanaan dan pengawasan dana desa. Peran masyarakat untuk memperoleh informasi pengelolaan dana desa dan terlibat aktif dibatasi, padahal. Undang-undang Desa dalam Pasal 68 mengatur tentang keterlibatan masyarakat dalam penggunaan anggaran desa, masyarakat punya hak dan kewajiban untuk mendapatkan informasi dan dilibatkan dalam pembangunan desa. Keterlibatan masyarakat merupakan hal yang sangat penting dan menjadi faktor paling utama karena masyarakat desa lebih mengetahui apa yang dibutuhkan desanya dan secara langsung dapat menyaksikan bagaimana pembangunan desanya. Namun, kenyataannya banyak masyarakat kurang peduli terhadap perkembangan desanya, karena tidak dilibatkan dalam perencanaan pembangunan desanya.

Faktor kedua, yang tidak kalah pentingnya adalah terbatasnya kemampuan kepala desa dan perangkat desa. rendahnya latar belakang tingkat pengetahuan dari kepala desa dan perangkat desa sangat berpengaruh akan faktor ini Keterbatasan ini akan mempengaruhi dalam melakukan pengelolaan dana desa, pengadaan barang dan jasa, serta laporan untuk penyusunan pertanggungjawaban keuangan desa.

Faktor ketiga, Tidak maksimalnya pelaksanaan lembaga desa. Terutama lembaga yang secara langsung mempunyai peran strategis dalam memberdayakan masyarakat dan pengambilan keputusan secara demokrasi tingkat desa, seperti lembaga Badan Permusyawaratan Desa (BPD).

Melihat kasus-kasus korupsi yang terjadi dalam pengelolaan dana desa, ada beberapa modus operandi yang dilakukan antara lain, yaitu :

1. Membuat RAB (Rancangan Anggaran Biaya) di atas harga pasar dan membayar tidak sesuai dengan harga pasar;

2. Bangunan fisik yang dibuat Kepala Desa dalam laporannnya dibiayai dari dana desa, padahal dananya bersumber dari dana lain.

3. Menggunakan dana desa untuk kepentingan pribadi.

4. Pemotongan dana desa oleh oknum pelaku

5. Membuat perjalanan dinas fiktif dengan cara memalsukan tiket penginapan/perjalanan;

6. Penggelembungan pembayaran honorarium perangkat desa;

7. Pembelian ATK tidak sesuai dengan real cost dengan cara pemalsuan bukti pembayaran;

8. Penggelapan dana pajak; dan.

9. Melakukan pembelian inventaris kantor dengan dana desa namun diperuntukkan secara pribadi. $^{9}$

8. Hasil Penelitian, diakses tgl 25 Agustus 2020 
Berkaitan dengan Upaya Pencegahan Korupsi Dalam Pengelolaan dana Desa, maka Peran serta masyarakat harus lebih berperan besar. Bagaimana mendorong partisipasi masyarakat untuk aktif, diperlukan petugas pendamping desa, karena pendamping desa. akan membimbing dan memberikan pendampingan masyarakat untuk melaporkan dalam hal menemukan adanya penyalahgunaan dana desa. Oleh karena itu yang penting dilakukan adalah membangkitkan partisipasi masyarakat. Karena tanpa itu agak sulit mencegah kebocoran dana desa.

Di samping partisipasi masyarakat, cara lainnya untuk pencegahan korupsi dana desa dengan meningkatkan kemampuan perangkat desa terkait pengelolaan Dana Desa. Dua hal tersebut akan memungkinkan kecurangan pengelolaan Dana Desa lebih rendah

\section{KESIMPULAN DAN SARAN}

Kegiatan Penyuluhan Hukum dapat terlaksana dengan baik, walapun dalam pelaksanaannya belum mencapai hasil yang maksimal, karena masih adanya bebeapa peserta belum menguasai dengan baik materi yang disampaikan. Kegiatan ini mendapat respon positif dari peserta, terbukti dengan peran aktif peserta mengikuti penyuluhan dengan tetap berada di tempat sebelum waktu kegiatan selesai.

Adanya kegiatan lanjutan yang pesertanya dapat melibatkan semua unsur masyarakat sehinga dapat meningkatkan parisipasi masyarakat dalam menentukan penggunaan dana desa.

\section{DAFTAR PUSTAKA}

Hanif Nurchlis, Pertumbuhan dan Penyelenggaraan Pemerintahan Desa, Erlangga, Jakarta, 2011.

Sahuri Lasmadi dan Elly Sudarti, Penyuluhan Hukum Tentang Merugikan Keuangan Negara Kepada Kepala Desa se-Kecamatan Pemayung Kabupaten Batang Hari Guna Pencegahan Korupsi pada Pemerintahan Desa, Jurnal Karya Abdi Masyarakat, $\underline{\text { Vol } 2}$ No 2 (2018): Volume 2, No (Issue) 2, Desember 2018

Trisno Yulianto, Desa Nol Korupsi, Undip, Koordinator Forum Kajian dan Transparansi Anggaran (Forkata), Tahun 2018

Yusrianto Kadir, Roy Marthen Moonri, Pencegahan Korupsi Dalam Pengelolaan Dana Desa, Jurnal IUS, Volume 6 No.3, Tahun 2018

Undang-Undang Nomor 31 Tahun 1999 Tentang Pemberantasan Tindak Pidana Korupsi sebagaimana diubah dengan Undang-Undang Nomor 20 Tahun 2001 Tentang Perubahan atas Undang-Undang Nomor 31 Tahun 1999 tentang Pemberantasan Tindak Pidana Korupsi

Undang-Undang Nomor 6 Tahun 2014 Tentang Desa 